Article

\title{
An Appraisal of Potential for Sowing of Nasturtium officinale into Streams to Mitigate Nutrient Pollution in Eastern Scotland
}

\author{
Andy Vinten ${ }^{1, *}$ and Patrick Bowden-Smith ${ }^{2}$ \\ 1 James Hutton Institute, Craigiebuckler, Aberdeen AB15 8QH, Scotland, UK \\ 2 Pittarthie Farm, Anstruther, Fife KY10 2RZ, Scotland, UK; cbowdensmith@aol.com \\ * Correspondence: andy.vinten@hutton.ac.uk
}

Received: 17 December 2019; Accepted: 27 January 2020; Published: 31 January 2020

check for updates

\begin{abstract}
This study examines a farmer-led initiative to sow watercress (Nasturtium officinale) in field ditches. The objective was to assess the potential of this practice to mitigate summer nutrient loads in rivers. Two ditches-one seeded, the other unseeded—on a mixed-livestock farm in Eastern Scotland were monitored during the spring-summer of 2014-2016. The un-replicated trial design limited statistical analysis. However, changes in $\mathrm{N}$ and $\mathrm{P}$ concentrations along the two ditches were measured. In the watercress-seeded ditch, $\mathrm{N}$ retention of $0.092 \mathrm{~g} / \mathrm{m}^{2} / \mathrm{d}(p<0.001, \mathrm{SE}=0.020)$ and $P$ retention of $0.0092 \mathrm{~g} / \mathrm{m}^{2} / \mathrm{d}(p=0.001, \mathrm{SE}=0.0028)$ occurred, while total organic $\mathrm{C}$ in the water increased along the ditch. Retention was close to zero for the unseeded ditch. The seeded ditch was also found to have more dry matter production and lower stream temperature. The impact of plastic covering (to increase spring temperature) on vegetation and nutrient removal was also assessed on replicate 5-m sections of the ditches. No significant impact on $\mathrm{N}$ and $\mathrm{P}$ removal was found; however, the release of $C$ increased significantly in the plastic-covered sections. The rise in air temperature (up to $>30^{\circ} \mathrm{C}$ ) promoted a greater growth of opportunist species (nettle (Urtica), rush (Juncus), and grasses. These observations were used to make a simple assessment of the potential catchment scale impact of seeding watercress into first and second order streams in the nearby Lunan Water catchment. It was concluded that this could make a significant contribution to the reduction of nutrient loads.
\end{abstract}

Keywords: watercress; stream nutrient retention; diffuse pollution mitigation

\section{Introduction}

It has been well established that macrophyte-associated nutrient retention in watercourses is an important sink for diffuse pollutants such as nitrogen $(\mathrm{N})$ and phosphorus $(\mathrm{P})$. Harvesting of macrophytes also has the potential for consumption or recycling to land [1,2]. Macrophytes regulate stream function via direct uptake of nutrients from water, by providing a substrate for epiphytic biofilms [3] and by slowing flow in both the water column and the hyporheic zone [4]. However, in some studies, workers have reached the conclusion that macrophytes have a large impact on trophic state in streams, but offer little potential to influence nutrient removal via management [5].

Watercress (Nasturtium officinale) is tolerant of a wide range of nutrient concentrations found in freshwater streams and is often a dominant member in streams with high nutrient loads [6]. Experiences in New Zealand [7-9] suggest that the luxury uptake of $\mathrm{N}$ by watercress (up to $4 \%$ of dry matter) may lead to substantial removal of $\mathrm{N}$ from polluted drainage water, particularly if it is harvested regularly. Field experiments have shown that young watercress plants are able to absorb $\mathrm{N}$ at a higher mass-specific rate, as compared to older plants [7]. 
In the interest of promoting citizen science [10], it is valuable to make use of farmer-led initiatives for pollutant mitigation, recognising that proactive uptake of government-led initiatives can be poor [11]. There is also the potential to be monetarily compensated on showing the required results [12] in an effort to boost the delivery of ecosystem services. A farmer-led initiative to sow watercress (Nasturtium officinale) in field ditches was appraised in this study. The objective was to assess the potential of seeding to mitigate summer $\mathrm{N}$ and $\mathrm{P}$ loads in river water. Two ditches-one seeded, the other unseeded-on a mixed-livestock farm in Eastern Scotland were monitored during the spring-summer of 2014-2016. The two ditches were on either side of a single grassland field in an upland, but relatively dry part of Eastern Scotland, at Pittarthie, an organic farm owned and managed by an innovative farmer with strong interest in ecological management [13]. The farmer also had prior experience and interest in growing watercress in polytunnels. The effect of enhancing the temperature of water to promote growth in spring/early summer using temporary plastic coverings over the ditches was also considered. Assessment of reduction in $\mathrm{N}$ and $\mathrm{P}$ loads along the ditches for six sampling dates over 2014-2016, and measurements of plant dry matter and N and P uptake were carried out, although the lack of replication of ditch treatments limited the statistical rigor of inferences from observations, highlighting an important potential limitation of such citizen science.

Diffuse pollution is a significant problem; it led to the failure of the water environment in Scotland achieving Good Ecological Status, as required by the EU Water Framework Directive [14]. Evidence is needed of the comparative effectiveness of potential mitigation measures, and Diffuse Pollution Monitored Catchments (DPMCs) were therefore established in Scotland to assess such measures at a catchment scale. One of these DPMCs, established in 2006, is the Lunan Water, a $134-\mathrm{km}^{2}$ catchment in Angus, Eastern Scotland. It is a typical lowland, mixed arable farmland catchment. Water flow and quality data has been collected in this catchment for $>10$ years [15]. A simple framework to assess the effectiveness and cost-effectiveness of a range of potential mitigation measures for P runoff from land ([16,17]), using a "smart" export coefficient approach, has also been developed. However, this approach did not consider retention of nutrients by aquatic vegetation. It was thus decided that it would be of great value to include this in the cost-effectiveness framework prescribed in this paper. Based on observations at Pittarthie, this study made a preliminary assessment of the potential impact of watercress seeding in the Lunan Water catchment.

\section{Materials and Methods}

\subsection{Study Area for Watercress Seeding Trial}

Pittarthie is a small, mixed livestock, 170-ha family farm located in eastern Fife, Scotland. Conservation of the water environment is a key theme at the farm, surrounding ponds, and wetlands. Fish ladders and silt traps were thus installed and other measures taken to control erosion via water margins. The monitoring reported here concerns two open ditches, which run down opposite edges of a south facing grass field that was cut for silage/hay production. One of these ditches was previously seeded with watercress. The ditches have a nominal 0.5-m wetted width during summer and drain into a small stream that runs into the Kinaldy Burn (has a Water Framework Directive ecological status of moderate). The location of these ditches is shown in Figure 1.

Ditch 1: Has natural growth of uncontrolled aquatic vegetation. Estimated catchment area of the ditch $=5.2$ ha. Length of the ditch below the highest sampling point $=280 \mathrm{~m}$. Mean slope $=0.033 \mathrm{~m} / \mathrm{m}$.

Ditch 2: Was seeded with watercress in 2013. Estimated catchment area of the ditch $=2.6$ ha. Length of ditch below the highest sampling point $=280 \mathrm{~m}$. Mean slope $=0.056 \mathrm{~m} / \mathrm{m}$.

In the spring of 2015 and 2016, a series of five 5-m longitudinal segments along the length of each ditch were covered with plastic polytunnel sheet with the objective of increasing spring air temperature and enhancing vegetative growth (Figure 2). The plastic was laid over a wire frame mounted around fence posts, weighed down with wooden battens along the sides of the ditch. These lengths were separated by uncovered sections. 


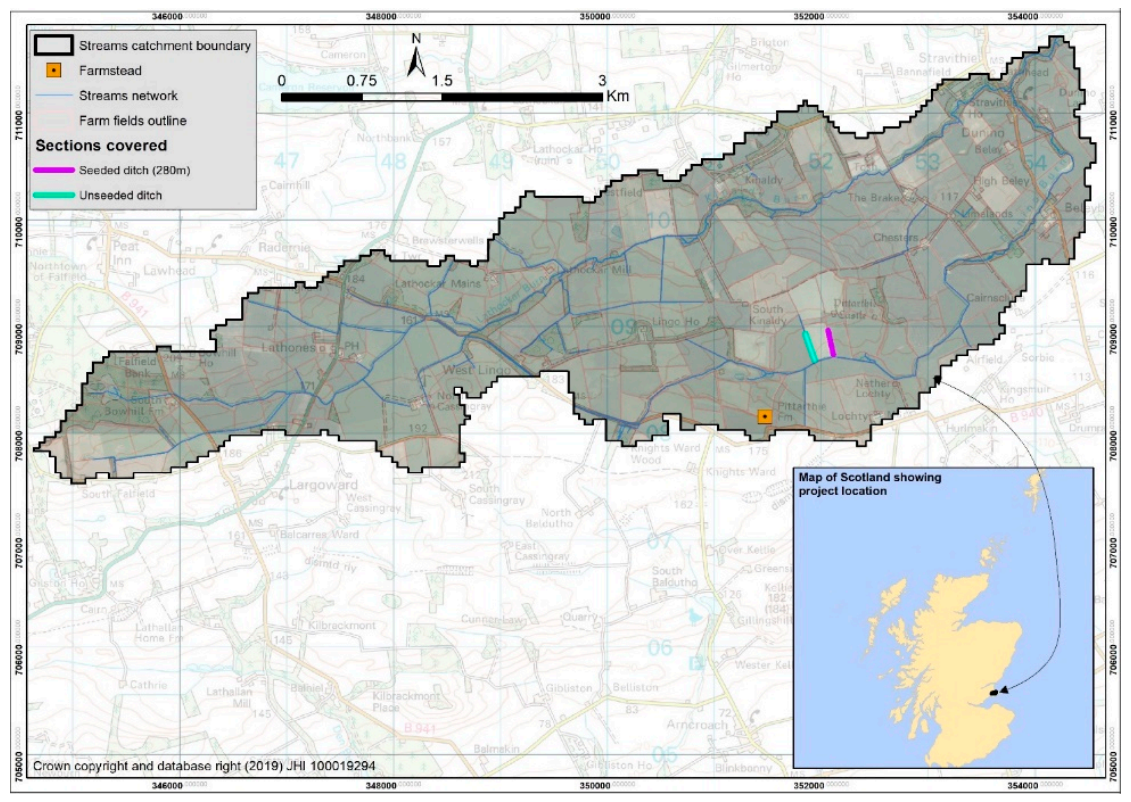

Figure 1. Location of the Pittarthie Farm watercress trial. Grid Reference No. 5150508136.



Figure 2. Seeded ditch in May 2014, showing uncovered and plastic-covered segments of the ditch.

\subsection{Estimation of Nutrient Retention by Ditches}

Water was sampled in transects along the ditches on three dates in 2014, one date in 2015, and two in 2016. Details of the water sampling are shown in Table 1. The samples were analysed by standard methods [15] for $\mathrm{pH}, \mathrm{EC}, \mathrm{NH}_{4}-\mathrm{N}, \mathrm{NO}_{3}-\mathrm{N}$, Total N, Org N, $\mathrm{PO}_{4}-\mathrm{P}$, Tot-P, Org-P, Total Organic C, Alkalinity, $\mathrm{K}$, and $\mathrm{Cl}$. 
Table 1. Timeline of plastic-covered treatments and sampling of ditches at Pittarthie Farm, 2014-2016.

\begin{tabular}{cccccc}
\hline Year/Month & Water Samples & $\begin{array}{c}\text { No. of Samples along } \\
\text { Seeded, Unseeded Ditches }\end{array}$ & $\begin{array}{c}\text { Plastic in Covered } \\
\text { Sections }\end{array}$ & $\begin{array}{c}\text { Vegetation } \\
\text { Samples }\end{array}$ \\
\hline 2014 & March & $13 / 03 / 2014$ & 5,6 & & \\
\hline 2014 & May & $30 / 05 / 14$ & 5,6 & Covered on $26 / 5 / 14$ & \\
\hline 2014 & August & $14 / 08 / 14$ & 5,6 & $\begin{array}{c}\text { Covers removed } \\
\text { after sampling }\end{array}$ & $10 / 06 / 2015$ \\
\hline 2015 & June & $10 / 06 / 15$ & 18,20 & Covered on $28 / 4 / 16$ & \\
\hline 2016 & April & $28 / 04 / 16$ & 22,22 & $\begin{array}{c}\text { Covers removed } \\
\text { after sampling }\end{array}$ & $30 / 05 / 2016$ \\
\hline 2016 & May & $30 / 05 / 16$ & 20,20 & &
\end{tabular}

The daily nutrient loading $\mathrm{L}_{\mathrm{N}, \mathrm{P}}(\mathrm{g} / \mathrm{d})$ at any sampling point distance $\mathrm{z}(\mathrm{m})$ along the ditch was estimated using Equation (1):

$$
\mathrm{L}_{\mathrm{N}, \mathrm{P}}(\mathrm{z})=86400 \mathrm{Y}_{\mathrm{N}, \mathrm{P}}(\mathrm{z}) \mathrm{Q}_{\mathrm{ditch}}
$$

where: $\mathrm{Y}_{\mathrm{N}, \mathrm{P}}(\mathrm{z})=\mathrm{N}, \mathrm{P}$ concentration in sample $(\mathrm{mg} / \mathrm{L}) ; \mathrm{Q}_{\text {ditch }}=$ mean daily flow in ditch $\left(\mathrm{m}^{3} / \mathrm{s}\right)$.

The value of $Q_{\text {ditch }}$ was estimated for each sampling date by scaling the observed daily flow data for the River Eden at Strathmiglo (56 $16^{\prime} 39.4^{\prime \prime}$ N $3^{\circ} 15^{\prime} 11.2^{\prime \prime}$ W) (obtained from the National River Flow archive [18] by the ratio of the area of the Eden catchment to the estimated area of the ditch catchment [19]:

$$
\mathrm{Q}_{\text {ditch }}=\mathrm{Q}_{\text {Eden }} \mathrm{A}_{\text {ditch catchment }} / \mathrm{A}_{\text {Eden catchment }}
$$

where: $Q_{\text {Eden }}=$ mean daily flow in River Eden $\left(\mathrm{m}^{3} / \mathrm{s}\right) ; \mathrm{A}_{\text {ditch catchment }}=$ catchment area of ditch estimated from field contours $\left(\mathrm{m}^{2}\right) ; \mathrm{A}_{\text {Eden catchment }}=$ catchment area of River Eden as stated in the National River Flow Archive $\left(\mathrm{m}^{2}\right)$.

The impact of ditch retention on nutrient loading at each sampling time $t, S_{N, P}(t)\left(g / m^{2} \operatorname{ditch} / d\right)$, was estimated from the slope of the regression line of $\Delta \mathrm{L}_{\mathrm{N}, \mathrm{P}}=\mathrm{L}_{\mathrm{N}, \mathrm{P}}(\mathrm{z})-\mathrm{L}_{\mathrm{N}, \mathrm{P}}(0)$ against distance $\mathrm{z}(\mathrm{m})$ down the ditch, and the assumed width of the wetted area of ditch, $\mathrm{W}(\mathrm{m})$ :

$$
\mathrm{S}_{\mathrm{N}, \mathrm{P}}(\mathrm{t})=\Delta \mathrm{L}_{\mathrm{N}, \mathrm{P}} / \mathrm{W} \Delta \mathrm{z}
$$

The changes in $\mathrm{NO}_{3}-\mathrm{N}, \mathrm{PO}_{4}-\mathrm{P}$ (SRP), and total dissolved organic $\mathrm{C}$ (TOC) loads from top to bottom of the ditch were analysed with GENSTAT $\left(19^{\text {th }}\right.$ edition) using general linear regression for groups. A students-t test was used to compare the slopes of these lines. Inspection of the data showed that some water samples had anomalously high $\mathrm{K}$ and/or $\mathrm{Cl}$ values, which we took to be evidence of the direct impact of fertilisers or manure. These sample data were removed from statistical analysis.

The impact of covering with plastic on water chemistry was analysed using ANOVA by comparing the change in solute concentration between successive sampling positions (UU: uncovered to uncovered; UC: uncovered to covered; CC: covered to covered; CU: covered to uncovered).

\subsection{Estimation of Plant Nutrient Uptake}

Nutrient retention is only partially controlled by plant nutrient uptake. In order to estimate plant nutrient uptake and compare it with the overall nutrient retention in the ditches, plant biomass (leaves and stems combined) was sampled in June 2015 and May 2016 from five 3-m sections of the ditches at successive sampling positions in the covered (C) and uncovered (U) parts. Width of the vegetation cover across the nominal $0.5-\mathrm{m}$ wetted width of ditch was noted. Above-ground dry matter content of watercress and other vegetation was determined by weighing samples before and after drying in an oven at $60^{\circ} \mathrm{C}$. The mean and standard deviation of dry matter for the covered and uncovered sections of the ditches were determined. For 2015 only, sub-samples of the vegetation samples were analysed 
for total N using a Thermo Finnigan Elemental Analyser, Thermo Fisher Scientific, Hemel Hempstead, UK (FlashEA 1112 Series).

Total P determination was done using inductively coupled plasma optical emission spectrometry (ICP-OES) analysis of a nitric acid digest of plant material. Total Plant uptake of $\mathrm{N}$ and $\mathrm{P}$ from seeding to the sampling date was calculated using Equation (4):

$$
\mathrm{UPT}_{\mathrm{N}, \mathrm{P}}=100 \times \mathrm{X}_{\mathrm{N}, \mathrm{P}} \times \mathrm{DM} \% \times \mathrm{FW}
$$

where: $\mathrm{UPT}_{\mathrm{N}, \mathrm{P}}=\mathrm{N}, \mathrm{P}$ uptake $\left(\mathrm{mg} / \mathrm{m}^{2}\right.$ stream surface); $\mathrm{X}_{\mathrm{N}, \mathrm{P}}=\% \mathrm{~N}, \mathrm{P}$ in dry matter of plant material (-); $\mathrm{DM} \%=\% \mathrm{DM}$ in samples of fresh plant material $(-) ; \mathrm{FW}=$ weight of fresh plant material harvested per $\mathrm{m}^{2}$ of stream surface area $\left(\mathrm{kg} / \mathrm{m}^{2}\right)$.

Note that for 2016, mean $X_{N, P}$ data from 2015 were used to estimate uptake, as there are no measurements of nutrient content of plant material. In addition, as the ditches are unreplicated, it is not possible to draw firm statistical inference from dry matter and nutrient uptake data, and no statistical test has been conducted on this data.

Temperature of the air and ditch water in each covered and uncovered section was noted on the sampling dates. In June 2016, the percent cover associated with watercress, grasses, other vegetation, and open water was determined by a quadrat on five $3 \mathrm{~m}$ lengths for the covered and uncovered sections in each ditch.

\subsection{Appraisal of Potential for Watercress Seeding in the Lunan Water Catchment}

To appraise the potential of watercress seeding, retention rate data from the Pittarthie trials were extrapolated to a catchment scale study in another mixed farming area in Eastern Scotland, the Lunan Water. Intensive monitoring of stream chemistry and flows has taken place for $>10$ years [15]. This catchment is of interest because within the upper catchment are two Lochs-Rescobie and Balgavies, covering $1.78 \mathrm{~km}^{2}$-which suffer from over-enrichment of nutrients, leading to serious eutrophication in summer and also affecting the Lunan Water downstream [20]. In addition, much of the catchment is underlain by porous groundwater bodies, vulnerable to nitrate pollution, which then reconnects with surface waters further downstream. Rescobie Loch had annual geomean values for TP (2003-2006) of $70.1 \mu \mathrm{g} / \mathrm{L}$, which implies a mean TP loading of $0.27 \mathrm{~kg} / \mathrm{ha}$ catchment/year. The target reduction in TP loading to achieve Good Ecological Status is $0.17 \mathrm{~kg} \mathrm{P} / \mathrm{ha}$ catchment/year.

The loading of $\mathrm{P}$ and $\mathrm{N}\left(\operatorname{load}_{\mathrm{P}, \mathrm{N}}\right)$ to the Lochs from the monitored Lunan sub-catchments was estimated using a combination of discharge estimation from $15 \mathrm{~min}$ water level data, 15 min turbidity monitoring, storm event sampling, and fortnightly spot samples [21]. For the present work, estimates of concentrations and loads were made for April 2010 to March 2012 for three sub-catchments: Lemno Burn, Balgavies Burn, and Baldardo Burn (Figure 3). Loads of TP were estimated using 15 min turbidity data and storm event-based calibrations of TP vs. turbidity [15,22]. Loads of $\mathrm{NO}_{3}-\mathrm{N}$ and Soluble Reactive Phosphorus (SRP) were estimated by interpolating fortnightly spot sampling and discharge data using the unbiased Beale estimator [15].

The impact of stream nutrient retention on nutrient loads to the loch, $\Delta \operatorname{load}_{\mathrm{N}, \mathrm{P}}$, was estimated using the following equation:

$$
\Delta \operatorname{load}_{\mathrm{N}, \mathrm{P}}=\mathrm{S}_{\mathrm{N}, \mathrm{P}}(\mathrm{t}) \Delta \mathrm{t} \mathrm{A}_{\text {stream }} / \mathrm{A}_{\text {catch }}
$$

where: $\Delta \operatorname{load}_{\mathrm{N}, \mathrm{P}}=$ change in N,P load from catchment to loch resulting from watercress-mediated retention $\left(\mathrm{g} / \mathrm{m}^{2}\right.$ catchment) over a time period; $\mathrm{S}_{\mathrm{N}, \mathrm{P}}(\mathrm{t})=$ retention rate of $\mathrm{N}, \mathrm{P}$ by watercress $\left(\mathrm{g} / \mathrm{m}^{2}\right.$ stream surface/d) (estimated from Equation (3)); $\mathrm{A}_{\text {stream }}=$ stream surface area in catchment $\left(\mathrm{m}^{2}\right.$ stream); $\mathrm{A}_{\text {catch }}=$ area of catchment $\left(\mathrm{m}^{2}\right.$ catchment $) ; \Delta \mathrm{t}=$ time period $(\mathrm{d})$. 


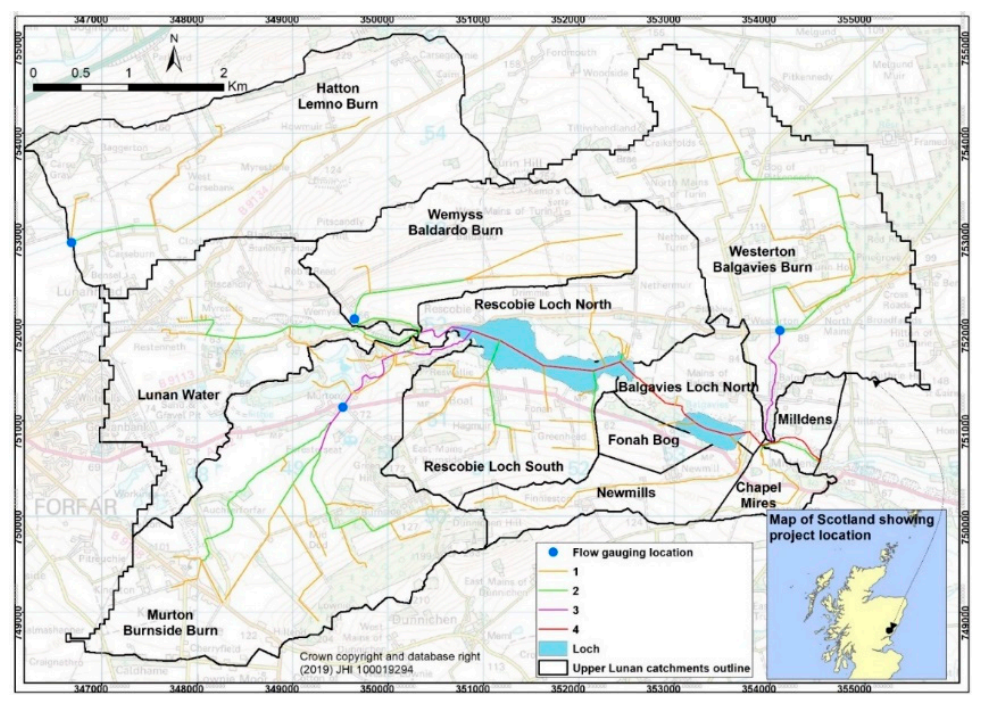

Figure 3. Sub-catchments in the upper Lunan Water. The flow gauging station/watercourse for the three monitored sub-catchments are: Westerton/Balgavies Burn $\left(\mathrm{A}_{\text {catch }}=590 \mathrm{ha}\right)$, Wemyss/Baldardo Burn $\left(\mathrm{A}_{\text {catch }}=238 \mathrm{ha}\right)$, and Hatton/Lemno Burn $\left(\mathrm{A}_{\text {catch }}=710 \mathrm{ha}\right)$. The total catchment area of Rescobie Loch is 2016 ha. The line colouring shows the stream order. Regular water chemistry sampling takes place at the three flow gauging stations and the SEPA run station at Murton/Burnside Burn.

\section{Results}

\subsection{Nutrient Retention}

For both $\mathrm{NO}_{3}-\mathrm{N}$ and SRP, water quality was well within the acceptable standards for rivers (Table 2). Nonetheless, these headwater concentrations contribute to nutrient loads lower down the catchment, where concentrations are higher.

Table 2. Mean and standard deviation of $\mathrm{NO}_{3}-\mathrm{N}$ and SRP concentrations in ditch and receiving stream samples.

\begin{tabular}{ccccccc}
\hline SRP $(\mu \mathrm{g} / \mathrm{L})$ & \multicolumn{2}{c}{2014} & \multicolumn{2}{c}{2015} & \multicolumn{2}{c}{2016} \\
\hline & Mean & SD & Mean & SD & Mean & SD \\
\hline Seeded ditch & 42 & 52 & 30 & 30 & 52 & 26 \\
Unseeded ditch & 49 & 38 & 27 & 19 & 33 & 6 \\
Receiving stream & 28 & 10 & & & 15 & 2 \\
\hline $\mathrm{NO}_{3}$-N(mg/L) & & & & & & \\
\hline Seeded ditch & 1.6 & 0.7 & 1.5 & 0.3 & 4.7 & 0.2 \\
Unseeded ditch & 2.0 & 1.2 & 0.6 & 0.1 & 1.5 & 0.3 \\
Receiving stream & 1.0 & 0.6 & & & 1.7 & 0.6 \\
\hline
\end{tabular}

$\mathrm{SD}=$ standard deviation.

Decline of SRP loads compared with estimated input loads along the seeded and unseeded ditches is shown in Figure 4a. All data are shown, except for June 2015 when there were large unexplained fluctuations in P load down the ditch, and between the first and second sampling points down the ditch for the seeded plot in August 2014 and the unseeded plot in May 2014. The high P concentrations in some of these samples correlated with high K concentrations, suggesting a direct fertiliser impact on the concentrations observed. There may have been issues with entrainment of sediment when sampling at low flows, which could affect $\mathrm{P}$ concentrations. On omitting these data from the analysis, general linear regression with groups shows a significant $(p=0.005)$ impact of seeding vs. non-seeding P removal rate (seeding: $-0.0092 \mathrm{~g} \mathrm{P} / \mathrm{m}^{2} \mathrm{ditch} / \mathrm{d}, p=0.001$; no seeding: $0.0024 \mathrm{~g} \mathrm{P} / \mathrm{m}^{2} \operatorname{ditch} / \mathrm{d}, p=\mathrm{NS}$ ). 
(a) P loads vs distance down ditch



(b) N loads vs distance down ditch

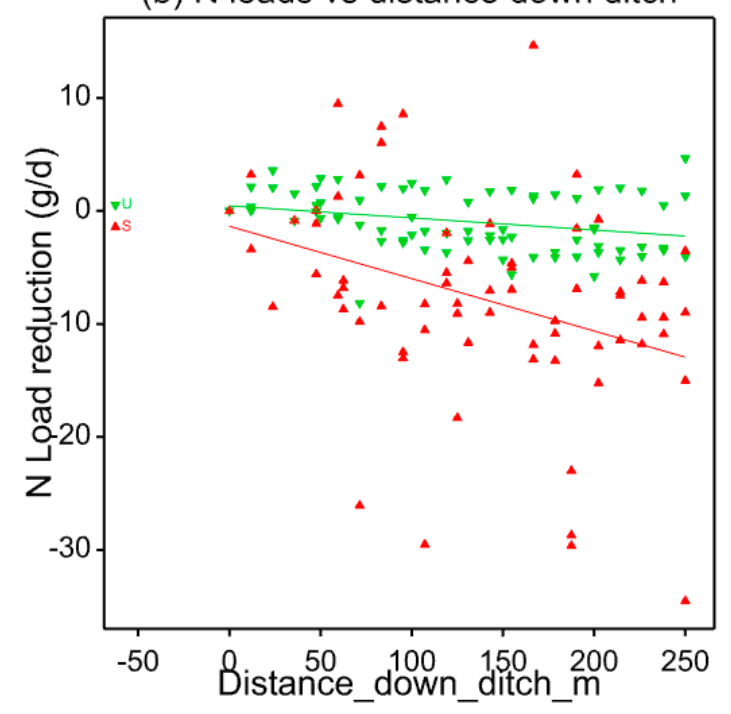

Figure 4. Estimation of (a) SRP and (b) $\mathrm{NO}_{3}-\mathrm{N}$ retention rates for ditches seeded with watercress, and those not seeded. Slopes of load reduction for watercress ditches (red) are equivalent to $-0.0092 \mathrm{~g}$ $\mathrm{P} / \mathrm{m}^{2} \mathrm{ditch} / \mathrm{d}$ and $-0.092 \mathrm{~g} \mathrm{~N} / \mathrm{m}^{2} \mathrm{ditch} / \mathrm{d}$, assuming an average ditch width of $0.5 \mathrm{~m}$.

Load reduction of $\mathrm{NO}_{3}-\mathrm{N}$ is shown in Figure $4 \mathrm{~b}$. There was an anomalously large reduction in $\mathrm{N}$ load between the first and second sampling points down both ditches for May 2014 and also for the unseeded ditch in March 2014. Omitting these data from the analysis, general regression analysis with groups shows a significant $(p=0.004)$ impact of seeding vs. non-seeding on $\mathrm{N}$ removal rate (seeding: $-0.092 \mathrm{~g} / \mathrm{m}^{2}$ ditch $/ \mathrm{d}, \mathrm{P}<0.001, \mathrm{SE}=0.010$; no seeding: $-0.022 \mathrm{~g} \mathrm{~N} / \mathrm{m}^{2} \mathrm{ditch} / \mathrm{d}, \mathrm{P}=\mathrm{NS}$ ). There were also several examples of a significant upward trend in TOC loads in both the seeded and unseeded ditches (see Supplementary Data 1).

\subsection{Effect of Plastic Covering}

The temperatures observed at the time of sampling in June 2015 and May 2016 are summarised in Table 3. The plastic covering greatly increased the daytime air temperature, particularly in the seeded 
ditch in June 2015. Water temperatures were lower on both dates in the seeded ditches than in the unseeded ones. Covering did not have a significant impact on water temperature.

Table 3. Mean air and water temperatures for the covered/uncovered sections of the seeded/unseeded ditches. Spot temperatures at time of sampling $(n=4$ or 5$)$.

\begin{tabular}{ccccccc}
\hline & & & \multicolumn{2}{c}{ June 2015 } & \multicolumn{2}{c}{ May 2016 } \\
& & & Air & Water & Air & Water \\
\hline SC & Seeded & Covered & 31.7 & 11.4 & 16.0 & 9.1 \\
SU & Seeded & Uncovered & 22.5 & 11.2 & 14.7 & 8.9 \\
UC & Unseeded & Covered & 29.0 & 16.4 & 17.0 & 11.1 \\
UU & Unseeded & Uncovered & n/a & 17.1 & 16.4 & 11.0 \\
\hline
\end{tabular}

The impact of plastic covering on water chemistry was analysed using ANOVA by comparing the change in solute concentration between successive sampling positions (UU: uncovered to uncovered; UC: uncovered to covered; CC: covered to covered; CU: covered to uncovered). No significant impact of the different transitions on change in water chemistry was found, except for a higher release rate of TOC in the covered sections.

\subsection{Growth and Nutrient Uptake}

Shoot dry matter yield in June 2015 and May 2016 is shown in Figure 5. There was a large difference between seeded and unseeded ditches in 2015 and although most of the dry matter in the unseeded ditch was associated with watercress, there was significantly more watercress growth in the seeded ditch. There was slightly more growth of watercress in the covered than in the uncovered ditches. In 2016, there was less growth of watercress in the covered sections than in the uncovered sections of the seeded ditch. The N and P content of the above-ground plant material in 2015 is shown in Figure 6. No distinction was made between watercress and other vegetation in the analysis. Nitrogen uptake was around $25 \mathrm{~kg} \mathrm{~N} / \mathrm{ha}$ of wetted ditch for the seeded ditch and P uptake was around $2 \mathrm{~kg} P / \mathrm{ha}$.

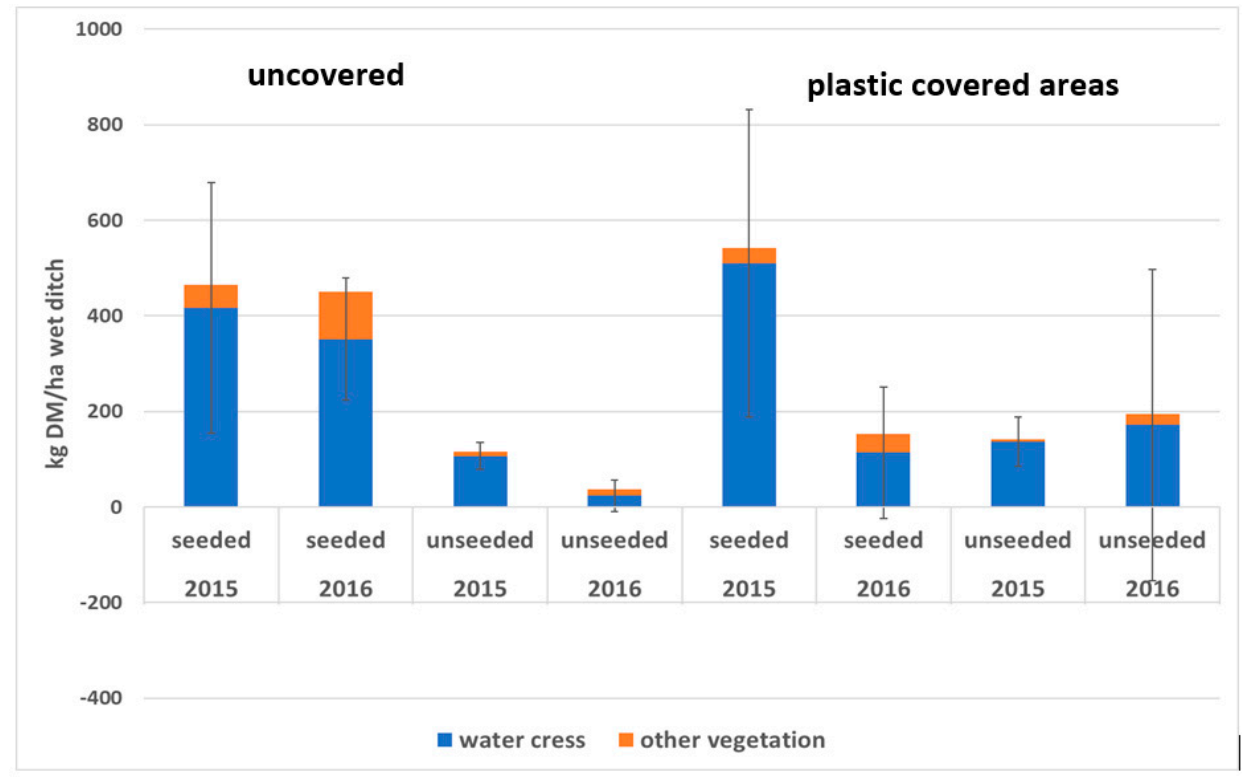

Figure 5. Average dry matter content and SD of above-ground growth in the seeded and unseeded ditches, for June 2015 and May 2016, uncovered and plastic covered areas, per unit wetted area of ditch. Width of the wet ditches is assumed to be $0.5 \mathrm{~m}$. The SD of watercress DM is also shown $(n=5)$. 


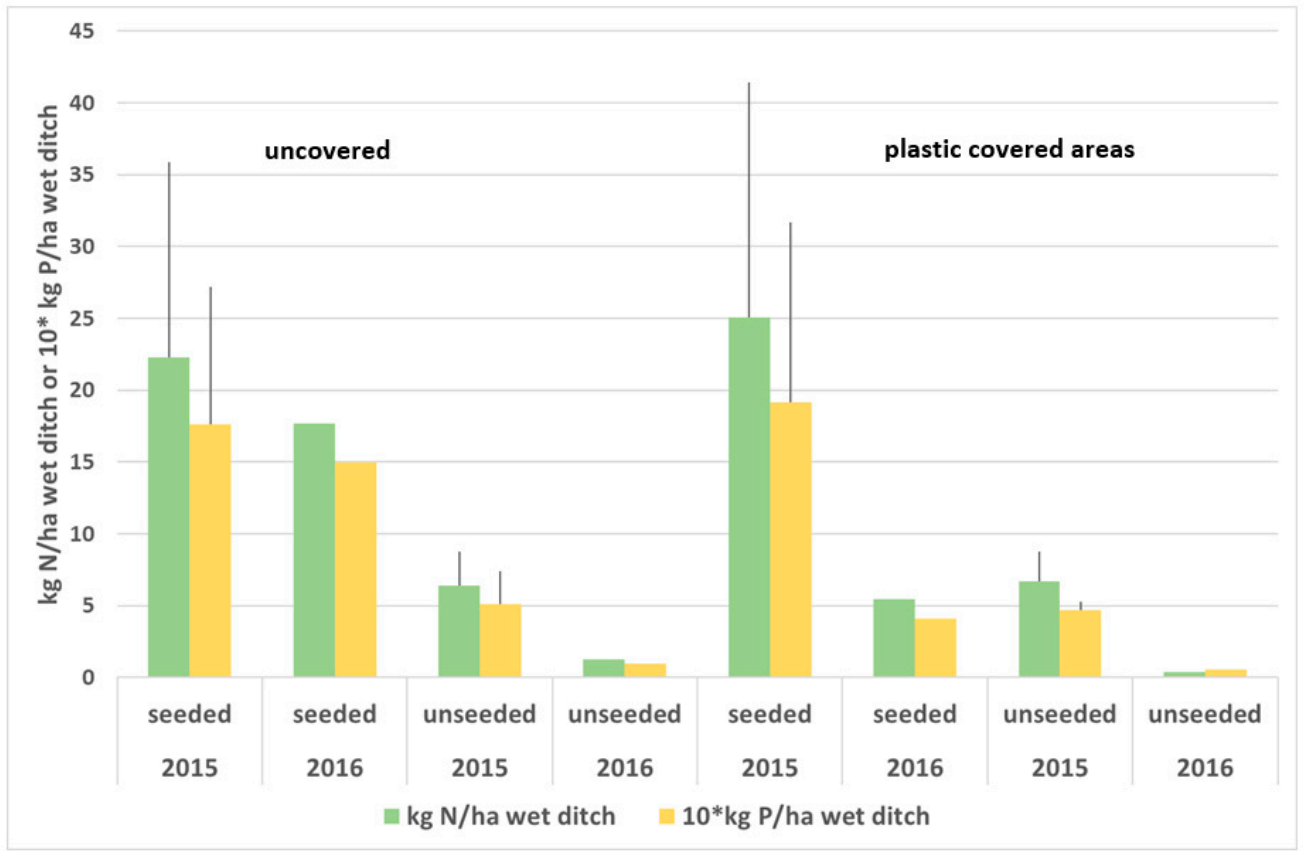

Figure 6. N and P content and SD of shoot of watercress in seeded and unseeded ditches, for June 2015 and May 2016, uncovered and plastic covered areas, per unit wetted area of ditch. Width of the wet ditches is assumed to be $0.5 \mathrm{~m}$. SD is also shown for $2015(n=5)$. Note that the 2016 results use treatment mean $\mathrm{N}$ and $\mathrm{P}$ content from 2015 to estimate uptake.

The \% cover of watercress, grass species, and other covers in the ditches in May 2016 is shown in Figure 7. This also shows that there was much less watercress growth (average 19\% cover) in the covered than the uncovered (33\% cover) seeded ditches. The covered sections of the unseeded ditch had similar watercress cover to the covered seeded sections. The plant species that invaded the ditches was a mix of grasses, dicots, and rushes. Although we did not measure species content in 2014, the seeded ditch was a more uniform stand of watercress in 2014, the year after seeding. Supplementary Information 2 shows examples of growth in the ditches.

The $\mathrm{N}$ uptake rates per unit of shoot dry matter were estimated for the two dates when dry matter data were available. These were 4.2 and $6.4 \mathrm{mg} \mathrm{N} / \mathrm{g}$ DM/d for June 2015 and May 2016, respectively. The P uptake rates were 0.09 and $0.2 \mathrm{mg}$ P/g DM/d for June 2015 and May 2016, respectively.

\subsection{Potential Impact of Watercress Seeding in Upper Lunan Water Catchment}

To make a preliminary assessment of the benefits of nutrient retention by seeding of watercress into streams and ditches in the Lunan Water catchment, the values of $S_{N, P}(t)$ were assumed to be $0.09 \mathrm{~g} \mathrm{~N} / \mathrm{m}^{2} / \mathrm{d}$ and $0.009 \mathrm{~g} \mathrm{P} / \mathrm{m}^{2} / \mathrm{d}$ for 4 months (April to July) and 0 during the rest of the year. These broad assumptions could be improved with a better understanding of seasonality of retention and growth of watercress, and by considering the impact of stream velocity on retention [22]; however, they should illustrate the potential of watercress seeding. By assuming a mean water surface area to catchment area ratio of 0.004 (using primary and secondary stream data from Figure 3), the impact of watercress seeding on $\mathrm{N}$ and $\mathrm{P}$ retention can then be estimated. Watercress requires suitable, low slope water courses, which maintain significant flows, and much of the upper Lunan Water catchment is of low slope, and hence amenable to macrophyte growth (Table 4). Note that the potential P retention exceeded the P load in the Balgavies sub-catchment during spring. If these values are upscaled to the Rescobie Loch catchment (Acatch $=1960$ ha), the estimates of load reduction by watercress seeding across the primary and secondary streams are found to be $85 \mathrm{~kg} \mathrm{P}$ (about $26 \%$ of the target P load reduction for the loch to achieve Good Ecological Status for P) and $852 \mathrm{~kg} \mathrm{~N}$. 

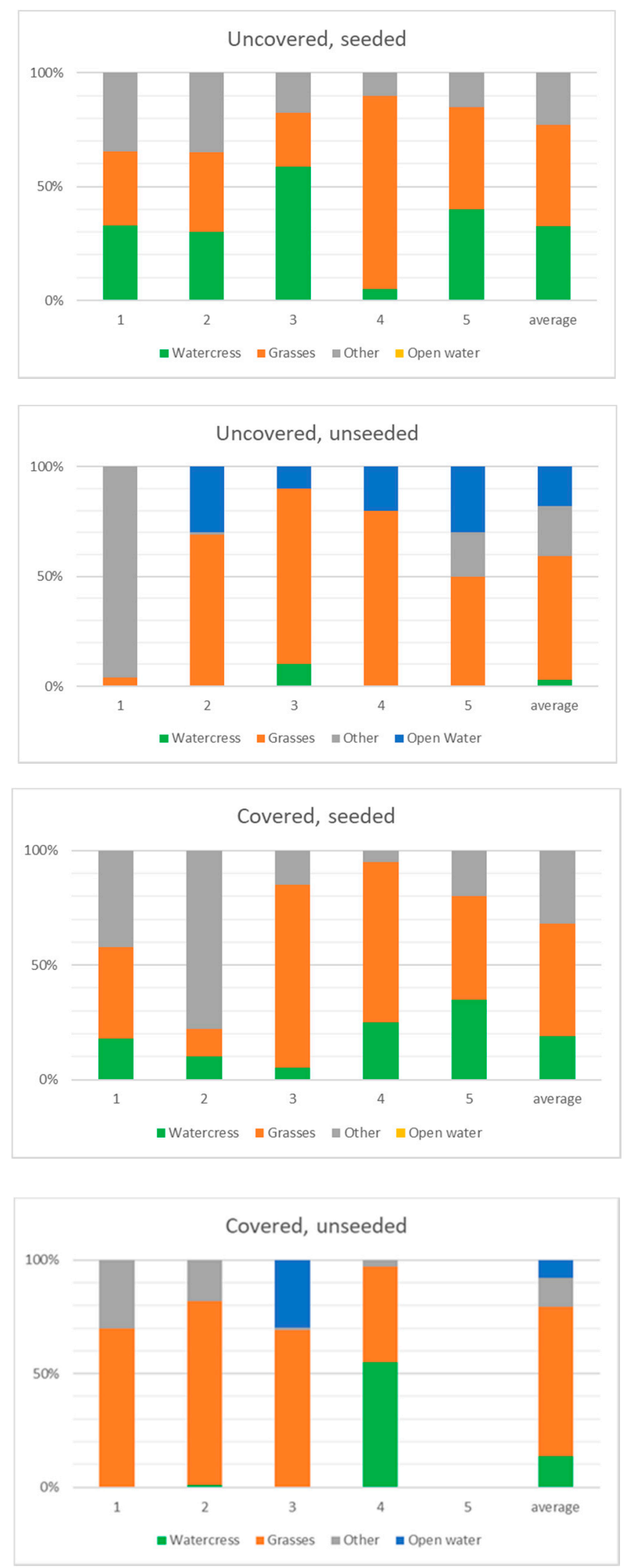

Figure 7. Percent cover of watercress, grasses, other plants, and open water in covered and uncovered, seeded and unseeded sections of ditches in May 2016. Other plants are mainly nettle (Urtica dioica), rush (Juncus effusus), with some Rumex, Violaceae, Galium, Ranunculus, Equisetum, Epilobium, and Onopordon spp. 
Table 4. Estimated impact of watercress seeding on $\mathrm{P}$ and $\mathrm{N}$ loads in upper Lunan Water sub-catchments.

\begin{tabular}{|c|c|c|c|c|c|c|c|c|c|}
\hline \multirow{2}{*}{$\begin{array}{c}\text { Sub- } \\
\text { Catchment }\end{array}$} & \multirow[t]{2}{*}{ Season } & \multicolumn{2}{|c|}{$\begin{array}{l}\text { TP Load } \\
\text { kg/ha }\end{array}$} & \multicolumn{2}{|c|}{$\begin{array}{c}\% \text { Reduction in } \\
\text { P Loads by Seeding }\end{array}$} & \multicolumn{2}{|c|}{$\begin{array}{c}\mathrm{NO}_{3}-\mathrm{N} \text { Load } \\
\mathrm{Kg} / \mathrm{ha}\end{array}$} & \multicolumn{2}{|c|}{$\%$ Reduction in N Loads } \\
\hline & & $2010-2011$ & 2011-2012 & $2010-2011$ & 2011-2012 & 2010-2011 & 2011-2012 & 2010-2011 & 2011-2012 \\
\hline \multirow{5}{*}{ Lemno } & autumn & 0.20 & 0.25 & $0.0 \%$ & $0.0 \%$ & 7.7 & 9.7 & $0.0 \%$ & $0.0 \%$ \\
\hline & winter & 0.59 & 0.13 & $0.0 \%$ & $0.0 \%$ & 17.6 & 9.6 & $0.0 \%$ & $0.0 \%$ \\
\hline & spring & 0.12 & 0.40 & $26.1 \%$ & $7.9 \%$ & 7.3 & 4.9 & $4.4 \%$ & $6.5 \%$ \\
\hline & summer & 1.32 & 0.20 & $0.9 \%$ & $5.8 \%$ & 24.8 & 11.3 & $0.5 \%$ & $1.0 \%$ \\
\hline & annual & 2.24 & 0.99 & $1.9 \%$ & $4.4 \%$ & 57.4 & 35.5 & $0.8 \%$ & $1.2 \%$ \\
\hline \multirow{5}{*}{ Baldardo } & autumn & 0.19 & 0.08 & $0.0 \%$ & $0.0 \%$ & 8.7 & 6.9 & $0.0 \%$ & $0.0 \%$ \\
\hline & winter & 0.27 & 0.06 & $0.0 \%$ & $0.0 \%$ & 17.8 & 6.5 & $0.0 \%$ & $0.0 \%$ \\
\hline & spring & 0.04 & 0.12 & $83.0 \%$ & $25.9 \%$ & 4.5 & 4.5 & $7.2 \%$ & $7.1 \%$ \\
\hline & summer & 0.11 & 0.07 & $10.4 \%$ & $17.3 \%$ & 9.2 & 8.5 & $1.2 \%$ & $1.4 \%$ \\
\hline & annual & 0.60 & 0.33 & $7.3 \%$ & $13.1 \%$ & 40.1 & 26.4 & $1.1 \%$ & $1.7 \%$ \\
\hline \multirow{5}{*}{ Balgavies } & autumn & 0.12 & 0.04 & $0.0 \%$ & $0.0 \%$ & 7.3 & 4.3 & $0.0 \%$ & $0.0 \%$ \\
\hline & winter & 0.18 & 0.02 & $0.0 \%$ & $0.0 \%$ & 23.6 & 5.3 & $0.0 \%$ & $0.0 \%$ \\
\hline & spring & 0.01 & 0.03 & $298.4 \%$ & $93.9 \%$ & 4.5 & 2.8 & $7.1 \%$ & $11.4 \%$ \\
\hline & summer & 0.07 & 0.03 & $15.7 \%$ & $34.5 \%$ & 7.8 & 10.3 & $1.5 \%$ & $1.1 \%$ \\
\hline & annual & 0.39 & 0.13 & $11.3 \%$ & $34.8 \%$ & 43.2 & 22.7 & $1.0 \%$ & $1.9 \%$ \\
\hline
\end{tabular}

\section{Discussion}

\subsection{Comparison with Other Work on Nutrient Retention by Macrophytes}

Our results are in keeping with the effect of macrophytes on nutrient retention observed by others. For example, Vincent and Downes [3] found a $6-11 \%$ loss of $\mathrm{N}$ mass over a $100-\mathrm{m}$ reach with watercress present, whereas no loss of $\mathrm{N}$ mass was measured over the same reach cleared of watercress. In the same Whangamata stream in New Zealand, estimated summer potential $\mathrm{N}$ and $\mathrm{P}$ retention rates were $0.41 \mathrm{mg} \mathrm{N} / \mathrm{m}^{2}$ watercourse/day and $0.019 \mathrm{mg} \mathrm{P} / \mathrm{m}^{2}$ watercourse/day, respectively [8] (assuming 100\% cover, area of river reach $=6000 \mathrm{~m}^{2}$ and mean flow of $70 \mathrm{~L} / \mathrm{s}$ ). Transient storage was approximately four times larger with watercress present compared with the same reach without the plants. $\mathrm{N}$ uptake rates by roots [6] were equivalent to $1.43 \mathrm{mg} \mathrm{N} / \mathrm{g}$ shoot DM/d in summer (water temperature $=13{ }^{\circ} \mathrm{C}$ ) and $0.52 \mathrm{mg} \mathrm{N} / \mathrm{g}$ shoot $\mathrm{DM} / \mathrm{d}$ in winter (water temperature $=10^{\circ} \mathrm{C}$ ). P uptake rate was $0.20 \mathrm{mg} \mathrm{P} / \mathrm{g}$ shoot $\mathrm{DM} / \mathrm{d}$ in summer. The uptake rate from the stream also depended on the mean percent cover of watercress, which varied from $20 \%$ (winter) to $42 \%$ (summer). In a range of natural streams in Western Europe [22], retention for $\mathrm{N}$ at low stream slopes was $0.3-0.5 \mathrm{~g} / \mathrm{m}^{2} / \mathrm{d}$ and for $\mathrm{P}$ it was $0.01-0.02 \mathrm{P} / \mathrm{m}^{2} / \mathrm{d}$; however, with higher slopes (and therefore shorter residence times), the retention rates were smaller. Seeding of streams is therefore likely to be most suitable where ditch slopes have shallow gradients. However, check-dams can be used to manage steeper sites and offer the advantage of promoting settling of sediment in pockets along the ditch length. Danish integrated buffer zones (IBZs) have shown $\mathrm{NO}_{3}-\mathrm{N}$ removal rates of $0.3-0.5 \mathrm{~g} \mathrm{~N} / \mathrm{m}^{2} / \mathrm{d}$ with efficiencies decreasing from $80 \%$ to $20 \%$ as $\mathrm{N}$ loads increased from 1 to $4 \mathrm{~g} \mathrm{~N} / \mathrm{m}^{2} /$ day, but very variable and even negative $P$ removal efficiencies occur [6].

\subsection{Factors Affecting Nutrient Retention}

It is important to note that only part of the impact of vegetation on nutrient retention is associated with plant uptake. For example, the average P uptake by the shoot material harvested in June 2015 was $0.18 \mathrm{~g} \mathrm{P} / \mathrm{m}^{2}$ in the seeded ditches and $0.05 \mathrm{~g} \mathrm{P} / \mathrm{m}^{2}$ for the unseeded ditches, equivalent to only $20 \mathrm{~d}$ of the observed nutrient retention rate. Accounting for root growth may increase the uptake figures by about $30 \%$ [7], but it is well known that the presence of vegetation also enhances retention of particulate material flowing past (including organic particulate material from periphyton), which may have a larger impact than the plant uptake itself. For example, a pattern of negative retention of $\mathrm{P}$ in summer was observed in the absence of submerged macrophytes but an average of $15 \%$ retention over April-August in the presence of macrophytes [23]. The average $\mathrm{N}$ uptake by the shoot material harvested in June 2015 was $2.2 \mathrm{~g} \mathrm{~N} / \mathrm{m}^{2}$ in the seeded ditches and $0.64 \mathrm{~g} \mathrm{~N} / \mathrm{m}^{2}$ for the unseeded ditches, equivalent to $24 \mathrm{~d}$ of the observed nutrient retention effect. Dissimilatory $\mathrm{N}$ reduction may be enhanced 
by the presence of $C$ released from plants [24]. The observed release of $C$ may also help to promote immobilisation of $\mathrm{N}$ and $\mathrm{P}$ in periphytic microbial biofilms [25]. It should be noted that watercress growth may extend into the non-wetted cross section. Here, it may not directly remove water from the stream, but from soil water, and so increase the amount of nutrient uptake [23].

It is also important to consider the annual pattern of $\mathrm{N}$ and $\mathrm{P}$ retention by the watercress. For example, in the Whangamata stream in New Zealand, there was an evident peak in uptake of $\mathrm{N}$ and $\mathrm{P}$ in the summer months [7]. This stream was spring fed and temperature of the water only varied from $10{ }^{\circ} \mathrm{C}$ in winter to $13^{\circ} \mathrm{C}$ in summer. This suggests that the annual pattern of uptake may be more related to growth stage and light than temperature. $\mathrm{N}$ and $\mathrm{P}$ retention in the Pittarthie ditches occurred earlier in the year and the highest $\mathrm{N}$ retention values were larger than that of the Whangamata stream, for similar levels of plant cover. This probably reflects the higher $\mathrm{N}$ concentrations in the water in the Pittarthie ditches and possibly the longer day length in late spring [26].

\subsection{Other Management Considerations}

Several other factors need to be considered when adopting the practice of watercress seeding in ditches and streams for water quality enhancement. For example, natural mustard oils present in watercress grown on farms may be released during disturbance (e.g., harvesting) and have a deterrent effect on invertebrates [27] such as Gammarus shrimps (Worgan and Tyrell, 2005, cited in [28]). However, for undisturbed beds, it is highly unlikely that the effects would be significant [29].

The growth of macrophytes also interacts strongly with a hydrological regime. Macrophyte cover is lowest in streams with high flow variability and highest in streams with long duration of low flow and low flow variability [30]. There is also evidence that increased growth of macrophytes will enhance water levels upstream [22]. If macrophytes are not removed during the high flow periods in the upper reaches of this catchment, this may promote retention of water during flood periods. This should be a benefit to downstream riparian owners, who suffer from periodic flooding, but it may not be beneficial to those in the upper catchment, who would appreciate better drainage of flood waters [31]. For this reason, seeding was restricted to first and second order streams, where unwanted flooding impacts would be less likely, although farmers would need to come to terms with less-efficient field drainage.

Farmers' perceptions of the importance of stewardship of water quality are increasing globally [32-34]. This is important for the achievement of both local enhancement of water quality (farm scale) and for downstream water users, and was an important driver of the research described here. Generating quantitative information has helped to support pro-environmental behaviour. It also helps to ground aspirations to improve water quality in the science challenge of demonstrating benefit. However, the un-replicated design of two ditches-one seeded and the other unseeded-limited the statistical rigour, and highlights the value of co-construction of trials between land managers and scientists, prior to implementation.

\section{Conclusions}

1. Watercress planting in drainage ditches on grassland under Scottish lowland conditions enhanced the retention of $\mathrm{N}$ and $\mathrm{P}$ during the growing period between April and August, compared with natural ditch vegetation (by $0.092 \mathrm{~g} \mathrm{~N} / \mathrm{m}^{2}$ wetted ditch $/ \mathrm{d}$ and $0.0092 \mathrm{~g} \mathrm{P} / \mathrm{m}^{2}$ wetted ditch/d). Only part of this retention can be explained by plant nutrient removal.

2. Plastic covering of ditch sections had a negative impact on watercress growth. The high air temperature (up to $>30^{\circ} \mathrm{C}$ ) promoted greater colonisation by opportunist species such as nettles (Urtica), rush (Juncus), and grasses. This way of enhancing spring aquatic plant growth is not recommended.

3. Estimates of potential watercress-mediated $\mathrm{N}$ and $\mathrm{P}$ retention for the Lunan Water catchment showed that loading into the eutrophic Rescobie and Balgavies Lochs in the upper catchment could be reduced by about $26 \%$ of the required load reductions, by targeting first and second 
order streams for watercress seeding. Seeding of streams is most suitable for shallow slopes with steady water flow.

4. Other factors need to be considered before adopting the practice of watercress seeding in ditches and streams for water quality enhancement, including potential re-release in periods of high flow, impact on stream ecology.

5. Ecology of release of natural mustard oils, impact on upstream water levels, and cost-effectiveness compared with other mitigation methods.

6. The farmer-led approach to use watercress-seeded ditches to mitigate diffuse pollution, supported by science-based evidence, has the potential to facilitate its adoption on a wider scale.

Supplementary Materials: The following are available online at http://www.mdpi.com/1660-4601/17/3/895/s1.

Author Contributions: Conceptualization, P.B.-S.; Investigation, A.V.; Methodology, P.B.-S.; Resources, P.B.-S.; Writing-original draft, A.V. All authors have read and agreed to the published version of the manuscript.

Funding: Andy Vinten was supported by Scottish Government's Rural and Environment Science and Analytical Services Division under the Strategic Research Program, Natural Assets Theme, grant number S100005-00.

Acknowledgments: We thank Jackie Potts of Biomathematics and Statistics Scotland for statistical support; Adekunle Ibiyemi for GIS support; and David Riach, Claire Abel and Helen Watson for field and laboratory support work. The work was heavily reliant on the support and encouragement of Patrick Bowden-Smith and others at Pittarthie Farm. We thank their interest, practical input, useful and interesting conservations, as well as for welcoming several field visits from policy makers and students, among others.

Conflicts of Interest: The authors declare no conflict of interest.

\section{References}

1. Iseyemi, O.O.; Farris, J.L.; Moore, M.T.; Choi, S.-E. Nutrient Mitigation Efficiency in Agricultural Drainage Ditches: An Influence of Landscape Management. Bull. Environ. Contam. Toxicol. 2016, 96, 750-756. [CrossRef]

2. Quilliam, R.S.; van Niekerk, M.A.; Chadwick, D.R.; Cross, P.; Hanley, N.; Jones, D.L.; Vinten, A.J.A.; Willby, N.; Oliver, D.M. Can macrophyte harvesting from eutrophic water close the loop on nutrient loss from agricultural land? J. Environ. Manag. 2015, 152, 210-217. [CrossRef]

3. Levi, P.S.; Riis, T.; Alnøe, A.B.; Peipoch, M.; Maetzke, K.; Bruus, C.; Baattrup-Pedersen, A. Macrophyte Complexity Controls Nutrient Uptake in Lowland Streams. Ecosystems 2015, 18, 914-931. [CrossRef]

4. Nikolakopoulou, M.; Argerich, A.; Drummond, J.D.; Gacia, E.; Martí, E.; Sorolla, A.; Sabater, F. Emergent Macrophyte Root Architecture Controls Subsurface Solute Transport. Water Resour. Res. 2018, 54, 5958-5972. [CrossRef]

5. O'Brien, J.M.; Lessard, J.L.; Plew, D.; Graham, S.E.; McIntosh, A.R. Aquatic Macrophytes Alter Metabolism and Nutrient Cycling in Lowland Streams. Ecosystems 2014, 17, 405-417. [CrossRef]

6. Zak, D.; Stutter, M.; Jensen, H.; Egemose, S.; Vodder Carstensen, M.; Audet, J.; Strand, J.; Feuerbach, P.; Hoffmann, C.; Christen, B.; et al. An Assessment of the Multifunctionality of Integrated Buffer Zones in Northwestern Europe. J. Environ. Qual. 2019, 48, 362-375. [CrossRef]

7. Vincent, W.F.; Downes, M.T. Variation in nutrient removal from a stream by watercress (Nasturtium officinale R. Br.). Aquat. Bot. 1980, 9, 221-235. [CrossRef]

8. Cox, T.J.; Rutherford, J.C. Nitrogen fate and transport in a watercress-dominated stream. N. Z. J. Mar. Freshw. Res. 2012, 46, 191-205. [CrossRef]

9. Nitrogen Management by Watercress (Nasturtium officinale) in Hydroponic Conditions. Available online: http://www.massey.ac.nz/ \{\}flrc/workshops/12/Manuscripts/Robertson_2012.pdf (accessed on 30 January 2020).

10. Conrad, C.C.; Hilchey, K.G. A review of citizen science and community-based environmental monitoring: Issues and opportunities. Environ. Monit. Assess. 2011, 176, 273-291. [CrossRef]

11. Okumah, M.; Chapman, J.P.; Martin-Ortega, J.; Novo, P. Mitigating Agricultural Diffuse Pollution: Uncovering the Evidence Base of the Awareness-Behaviour-Water Quality Pathway. Water 2018, 11, 29. [CrossRef] 
12. Sidemo-Holm, W.; Smith, H.G.; Brady, M.V. Improving agricultural pollution abatement through result-based payment schemes. Land Use Policy 2018, 77, 209-219. [CrossRef]

13. RSPB. Giving Nature a Home. Available online: https://www.rspb.org.uk/our-work/conservation/ conservation-and-sustainability/farming/case-studies/scotland/ (accessed on 30 January 2020).

14. Water Framework Directive in Scotland (WFD). Available online: http://www.gov.scot/Topics/Environment/ Water/15561/WFD (accessed on 30 January 2020).

15. Dunn, S.M.; Sample, J.; Potts, J.; Abel, C.; Cook, Y.; Taylor, C.; Vinten, A.J.A. Recent trends in water quality in an agricultural catchment in Eastern Scotland: Elucidating the roles of hydrology and land use. Environ. Sci. Process. Impacts 2014, 16, 1659-1675. [CrossRef]

16. Vinten, A.; Sample, J.; Ibiyemi, A.; Abdul-Salam, Y.; Stutter, M. A tool for cost-effectiveness analysis of field scale sediment-bound phosphorus mitigation measures and application to analysis of spatial and temporal targeting in the Lunan Water catchment, Scotland. Sci. Total Environ. 2017, 586, 631-641. [CrossRef]

17. Balana, B.B.; Lago, M.; Baggaley, N.; Castellazzi, M.; Sample, J.; Stutter, M.; Slee, B.; Vinten, A. Integrating Economic and Biophysical Data in Assessing Cost-Effectiveness of Buff er Strip Placement. J. Environ. Qual. 2012, 41, 380-388. [CrossRef]

18. National River Flow Archive. Available online: https://nrfa.ceh.ac.uk/ (accessed on 30 January 2020).

19. Gianfagna, C.C.; Johnson, C.E.; Chandler, D.G.; Hofmann, C. Watershed area ratio accurately predicts daily streamflow in nested catchments in the Catskills, New York. J. Hydrol. Reg. Stud. 2015, 4, 583-594. [CrossRef]

20. Birkel, C.; Tetzlaff, D.; Dunn, S.M.; Soulsby, C. Using lumped conceptual rainfall-runoff models to simulate daily isotope variability with fractionation in a nested mesoscale catchment. Adv. Water Resour. 2011, 34, 383-394. [CrossRef]

21. Stutter, M.; Dawson, J.J.C.; Glendell, M.; Napier, F.; Potts, J.M.; Sample, J.; Vinten, A.; Watson, H. Evaluating the use of in-situ turbidity measurements to quantify fluvial sediment and phosphorus concentrations and fluxes in agricultural streams. Sci. Total Environ. 2017, 607, 391-402. [CrossRef]

22. De Klein, J.J.M.; Koelmans, A.A. Quantifying seasonal export and retention of nutrients in West European lowland rivers at catchment scale. Hydrol. Process. 2011, 25, 2102-2111. [CrossRef]

23. Eugene Turner, R.; Bodker, J.E.; Schulz, C. The belowground intersection of nutrients and buoyancy in a freshwater marsh. Wetl. Ecol. Manag. 2018, 26, 151-159. [CrossRef]

24. Washbourne, I.J.; Crenshaw, C.; Baker, M. Dissimilatory nitrate reduction pathways in an oligotrophic freshwater ecosystem: Spatial and temporal trends. Aquat. Microb. Ecol. 2011, 65, 55-64. [CrossRef]

25. Tank, J.L.; Martí, E.; Riis, T.; von Schiller, D.; Reisinger, A.J.; Dodds, W.K.; Whiles, M.R.; Ashkenas, L.R.; Bowden, W.B.; Collins, S.M.; et al. Partitioning assimilatory nitrogen uptake in streams: An analysis of stable isotope tracer additions across continents. Ecol. Monogr. 2018, 88, 120-138. [CrossRef]

26. Going, B.; Simpson, J.; Even, T. The influence of light on the growth of watercress (Nasturtium officinale R. Br.). Hydrobiologia 2008, 607, 75-85. [CrossRef]

27. Newman, R.M.; Kerfoot, W.C.; Hanscom, Z. Watercress Allelochemical Defends High-Nitrogen Foliage Against Consumption: Effects on Freshwater Invertebrate Herbivores. Ecology 1996, 77, 2312-2323. [CrossRef]

28. Cox, J. Watercress Growing and Its Environmental Impacts on Chalk Rivers in England, NECR ed.; NECR027; Natural England: York, UK, 2009.

29. Cotter, S. Impact of Watercress Farming on Stream Ecosystem Functioning and Community Structure. Ph.D. Thesis, Queen Mary University of London, University of London, London, UK, September 2012.

30. Riis, T.; Suren, A.; Clausen, B.; Sand-Jensen, K.A.J. Vegetation and flow regime in lowland streams. Freshw. Biol. 2008, 53, 1531-1543. [CrossRef]

31. Vinten, A.; Kuhfuss, L.; Shortall, O.; Stockan, J.; Ibiyemi, A.; Pohle, I.; Gabriel, M.; Gunn, I.; May, L. Water for all: Towards an integrated approach to wetland conservation and flood risk reduction in a lowland catchment in Scotland. J. Environ. Manag. 2019, 246, 881-896. [CrossRef]

32. Okumah, M.; Yeboah, A.S. Exploring stakeholders' perceptions of the quality and governance of water resources in the Wenchi municipality. J. Environ. Plan. Manag. 2019, 1-29. [CrossRef] 
33. Withanachchi, S.S.; Ghambashidze, G.; Kunchulia, I.; Urushadze, T.; Ploeger, A. Water Quality in Surface Water: A Preliminary Assessment of Heavy Metal Contamination of the Mashavera River, Georgia. Int. J. Environ. Res. Public Health 2018, 15, 621. [CrossRef]

34. Withanachchi, S.; Ploeger, A.; Al Sidawi, R.; Kunchulia, I.; Ghambashidze, G.; Urushadze, T. Farmers' Perception of Water Quality and Risks in the Mashavera River Basin, Georgia: Analyzing the Vulnerability of the Social-Ecological System through Community Perceptions. Sustainability 2018, 10, 3062. [CrossRef]

(C) 2020 by the authors. Licensee MDPI, Basel, Switzerland. This article is an open access article distributed under the terms and conditions of the Creative Commons Attribution (CC BY) license (http://creativecommons.org/licenses/by/4.0/). 